\title{
Experimental Investigation of the Partial Vegetation Effect on the Flood Wave Propagation Resulted from Dam Failure in Urkmez Residential Area by means of Distorted Physical Model
}

\author{
Ürkmez Yerleşim Alanında Baraj Yıkılması Sonucunda \\ Oluşan Taşkın Dalgalarının Yayılmasında Kısmi Bitki \\ Örtüsü Etkisinin Çarpıtılmış Fiziksel Model ile Deneysel \\ Olarak Araștırılması
}

\author{
Emrah Sevinç 1(), Mehmet Şükrü Güney 2 (1) \\ ${ }^{1}$ Dokuz Eylül Üniversitesi Fen Bilimleri Enstitüsü, Hidrolik-Hidroloji ve Su Kaynakları Programı, İzmir, TÜRKIYE \\ 2 İzmir Ekonomi Üniversitesi Mühendislik Fakültesi, İnşaat Mühendisliği Bölümü, İzmir, TÜRKIYE \\ Sorumlu Yazar / Corresponding Author*: emrahsvnc@yahoo.com \\ Geliş Tarihi / Received: 09.12.2020 \\ Araştırma Makalesi/Research Article \\ Kabul Tarihi / Accepted: 14.04.2021 \\ DOI:10.21205/deufmd.2021236909 \\ Atıf șekli/How to cite: SEVINC E., GUNEY M.S.(2021). Experimental Investigation of the Partial Vegetation Effect on the Flood Wave \\ Propagation Resulted from Dam Failure in Urkmez Residential Area by means of Distorted Physical Model. DEUFMD 23(69), 803-821.
}

\begin{abstract}
The purpose of this study is to investigate the effect of partial vegetation on the wave propagation resulted from sudden dam failure in a residential area. Temporal variations of water depths and flood wave propagation velocities were determined and compared with those obtained from the experiments performed without vegetation. The experiments were performed on the distorted physical model of Urkmez Dam and its downstream region. The distorted physical model with horizontal scale of $1 / 150$ and vertical scale of $1 / 30$ contains the dam reservoir, the dam body, the residential area of Urkmez coastal town until the sea and the partial vegetation. In the model, the reservoir has an active volume of $11.222 \mathrm{~m}^{3}$, the dam body has a length of $2.84 \mathrm{~m}$ and a height of 1.07 $\mathrm{m}$, and the downstream area is nearly $200 \mathrm{~m}^{2}$. Water depths were measured by e+ WATER L level sensors placed at various locations of the downstream region. Velocities were measured by ultrasonic velocity profilers (UVP) located near the level sensors. Flood wave propagation was recorded by the high definition digital camera. Experimental findings obtained from the physical model were converted to the prototype values, in nature. The changes in water depths and elapsed times, also the changes in velocities and their occurrence times were determined for different zones of the downstream area in the presence of vegetation. The experimental results revealed that in such a dam failure, the flood arrives at the sea in $6 \mathrm{~s}$ in the absence of vegetation, while in $10 \mathrm{~s}$ in the presence of vegetation. These values correspond to $2.74 \mathrm{~min}$ and $4.57 \mathrm{~min}$, respectively in the prototype. The existence of vegetation resulted in decrease in flood propagation velocities mainly in the dense residential area, as expected. It was observed that the maximum water depths were increased at the left bank and decreased at the right bank, except at level sensor S6 which is very close to the creek. It was observed that the maximum depth averaged velocities were decreased in the sparse and dense residential areas. The existence of the vegetation changed considerably the local velocities during
\end{abstract}




\section{DEÜ FMD 23(69), 803-821, 2021}

rising and recession stages of the water depth. It was found that the order of magnitude of the prototype velocities was high and such velocities can cause serious damage mainly in the buildings close to the dam body. Because the presence of vegetation caused a decrease in flood propagation velocities in the sparse and dense residential areas, it would reduce the damages on the buildings in these areas.

Keywords: Distorted physical model, Sudden dam break, Vegetation effect, Flood wave propagation

\section{Öz}

$\mathrm{Bu}$ çalışmanın amacı, bir yerleșim bölgesindeki ani baraj yıkılması ile meydana gelen dalga yayılmasında bitki örtüsünün etkisinin araștırılmasıdır. Su derinliklerinin zamana bağlı değişimleri ve taşkın dalgası yayılma hızları belirlenmiş ve bitki örtüsüz yapılan deneylerden elde edilenlerle karşılaştırılmıştır. Deneyler, Ürkmez Barajı ve mansap bölgesinin çarpıtılmış fiziksel modeli üzerinde gerçekleștirilmiştir. 1/150 yatay ölçekli ve 1/30 düşey ölçekli çarpıtılmış fiziksel model, baraj haznesi, baraj gövdesi, Ürkmez sahil kasabasının denize kadar olan yerleşim alanını ve kısmen bitki örtüsünü içermektedir. Modelde hazne aktif hacmi $11.222 \mathrm{~m}^{3}$, baraj gövdesi $2.84 \mathrm{~m}$ uzunluğunda ve $1.07 \mathrm{~m}$ yüksekliğinde olup mansap bölgesi alanı yaklaşık $200 \mathrm{~m}^{2}$ dir. Su derinlikleri, mansap bölgesinin çeşitli yerlerine yerleștirilen e + WATER L seviye ölçerleri ile ölçülmüştür. Hızlar, seviye ölçerlerin yakınında bulunan ultrasonik hız ölçüm cihazları (UVP) ile belirlenmiștir. Taşkın dalgasının yayılması, yüksek çözünürlüklü dijital kamera ile kaydedilmiştir. Fiziksel modelden elde edilen deneysel bulgular, doğadaki prototip değerlerine dönüștürülmüștür. Su derinliklerindeki ve geçen sürelerdeki değișimler, ayrıca hızlardaki değișimler ve bunların oluşma süreleri, bitki örtüsünün varlığında mansap bölgesinin farklı bölgeleri için belirlenmiştir. Deneysel sonuçlar bu tür bir baraj yıkılmasında, taşkının bitki örtüsü olmadan 6 saniyede, bitki örtüsü varlığında ise 10 saniyede denize ulaştığını ortaya koymuştur. Bu değerler prototipte sırasıyla 2.74 dakika ve 4.57 dakikaya karşılık gelmektedir. Bitki örtüsünün varlığı, beklendiği gibi, özellikle yoğun yerleşim alanlarında taşkın yayılma hızlarında düșüșe neden olmuștur. Maksimum su derinliklerinin sol sahilde arttı̆̆ ve sağ sahilde dereye çok yakın olan S6 seviye ölçeri dışında azaldığı görülmüştür. Seyrek ve yoğun yerleşim bölgelerinde derinlik ortalamalı maksimum hızların azaldığı gözlemlenmiștir. Bitki örtüsü varlığının, su derinliğinin yükselme ve alçalma safhalarında yerel hızları önemli ölçüde değiştirdiği tespit edilmiştir. Prototipteki hızların önemli mertebede olduğu ve bu hızların özellikle baraj gövdesine yakın binalarda ciddi hasarlara neden olabileceği ortaya çıkmıştır. Bitki örtüsü varlığının seyrek ve yoğun yerleşim alanlarında taşkın yayılma hızlarını azaltmış olması nedeniyle, bu bölgelerde bulunan binalardaki hasarları da azaltmış olacaktır.

Anahtar Kelimeler: Çarpıtılmış fiziksel model, Ani baraj yıkılması, Bitki örtüsü etkisi, Taşkın dalgası yayılması

\section{Introduction}

Dams are constructed to supply potable water, irrigation water, power generation, flood protection, recreation area etc. Dams which improve the living standards by providing significant benefits to the society, can also cause extremely serious disasters to the same society if they are failed. In the case of sudden or partial dam failure, a large amount of water stored in the dam reservoir turns into a flood wave and can cause loss of life and property of the people living in the downstream area. The greatest damages occur in the case of sudden dam failure [1].

Therefore, scenarios concerning physical and numerical models that contain the dam reservoir, the dam body and downstream region of the dam are of great importance.

In literature, several experimental studies have been carried out on dam failure and flood wave propagation. In most of these studies, experiments have been performed in a rectangular channel and three-dimensional structure of the problem could not be taken into account. Water level changes have been measured in certain points placed at upstream and downstream regions and limited information has been obtained in only a few points [2].

Recently, the flow in a vegetated channel attracted interests for flood protection and 
numerous experimental and numerical studies were undertaken. Vegetation generally increases the flow resistance, changes the velocity distribution, and affects the discharge capacity and sediment transport rate [3]. Yang et al. [3] studied experimentally the velocity distribution of flows in different types of vegetation such as grass, shrubs and trees. Acoustic Doppler Velocitymeter (ADV) was used to measure the local flow velocities. The experiments were undertaken in an asymmetric compound channel. The grass and shrubs retarded the flow more than the trees. The velocity at the main channel/floodplain interface decreased as the bed slope decreased. Even though the bed slope was different, the velocity distribution was found to be similar. Chen et al. [4] investigated the transverse distributions of the depth averaged velocity and the Reynolds stresses in a steady uniform flow in partially vegetated rectangular channels. They used the Micro ADV to measure the steady uniform flow with emergent artificial rigid vegetation. Comparisons between the analytical results and the experimental data showed that their proposed method could well predict the depthaveraged velocity and the Reynolds stresses. Zhang et al. [5] applied a vertical twodimensional numerical model to study some free surface problems including pure current, solitary wave, regular and random wave propagation with and without vegetation. The calculated results showed that the wave height decay followed the same trends for all the cases due to resistance impact, whatever rigid and flexible vegetation or submerged and emergent vegetation. For regular wave and random wave over flexible vegetation, this model predicted correctly the decay of wave height along the channel in the presence of the vegetation. The rate of decay was dependent on the wave height, the vegetation density, etc. Whatever the random wave, the regular wave or solitary wave condition was, the presence of vegetation increased the attenuation of the wave height and the energy dissipation. Zhang et al. [6] developed a model validated with several types of flood propagation problems, including dam-break flows over fixed and mobile beds under the conditions with and without aquatic plants. The results showed that the riparian vegetation in the waterway narrows the channel and reduces the conveyance capacity of river. The plants restricted the flow by forming a buffer against the flood. The resistance of plants markedly reduced the flow velocity, which directly altered the fluvial processes and influenced the waterway morphology. He et al. [7] developed a model for dam-break flows over mobile and vegetated beds, and also simulated laboratory experiments to validate the model. The good agreements between the measurements and the numerical simulations demonstrated a satisfactory performance of the model in reproducing the flow depth, velocity and bed deformation depth. It was revealed that the vegetation may divert the direction of the main flow, hindering the flow and thus results in increased deposition upstream of the vegetation. Li et al. [8] examined the effects of vegetation density on the flow velocity characteristics. Rigid bamboo circular cylinders were chosen as the model emergent vegetation. For all the experiments, the density of vegetation was altered while all other flow parameters were kept constant. ADV was used to measure the local flow velocities for different vegetation densities. The results showed that the existence of vegetation patch facilitates the increase of depth-averaged velocity on the right and left side behind the vegetation patch, and it increased monotonically with vegetation density. Guney et al. [9], investigated experimentally the flood propagation due to partial dam break resulting from a trapezoid-shaped breach by using the distorted physical model of Urkmez Dam. The experimental results show that the Urkmez area can be flooded in a matter of minutes, at depths reaching up to $3 \mathrm{~m}$. The flood wave front could reach the residential areas in 2 min and the sea coast in $4 \mathrm{~m}$. Oguzhan and Aksoy [10], differently from this study presented here, investigated experimentally the effects of more dense vegetation on the flood wave propagation in the case of dam break by using the distorted physical model of Urkmez Dam. The dam break scenarios were achieved by means of rectangular and triangular gates for the dam reservoir levels 98 $\mathrm{cm}, 88 \mathrm{~cm}$ and $80 \mathrm{~cm}$. The analysis of the experimental data showed that the presence of vegetation causes a significant decrease in water depths as the flood wave propagates to the downstream and greatly reduces its impact on the settlements. It was also revealed that dam break shape plays an important role in temporal variation of flood wave.

In this study, the effect of partial vegetation on the wave propagation resulted from sudden dam 
failure in a residential area, was investigated by means of the distorted physical model corresponding to Urkmez Dam and its downstream region. Some experimental results performed under different experimental conditions were presented as an oral presentation at the $5^{\text {th }}$ International Symposium on Dam Safety held in Istanbul on 27-31 October 2018 [11].

\section{Material and Method}

\subsection{Design of the distorted physical model}

The distorted physical model of Urkmez Dam and its downstream region was designed to investigate flood wave propagation resulted from partial and sudden dam failure [12]. General view of the studied area is given in Figure 1.

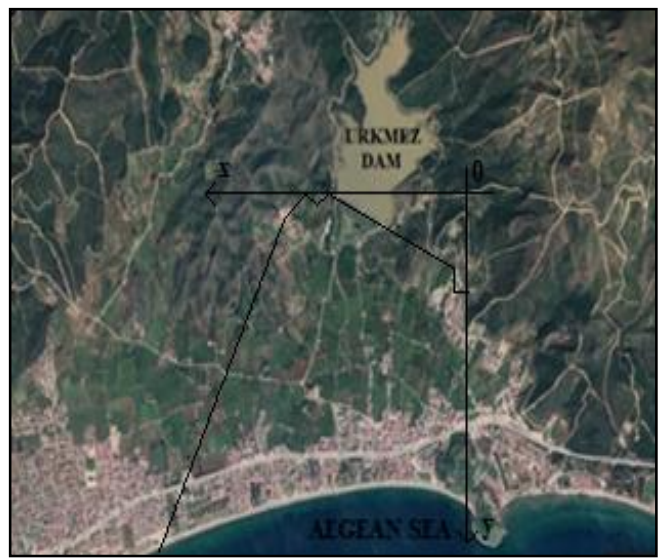

Figure 1. General view of the studied area [13]

The distorted physical model of Urkmez dam together with reservoir and downstream region was studied according to the Froude similitude law since the gravitational force is dominant. The horizontal and vertical scales of the model were selected, as $S\left(L_{x}\right)=1 / 150$ and $S\left(L_{z}\right)=1 / 30$, respectively, in order to be able to build it in the available area and measure water depths and velocities with sufficient accuracy.

The distortion ratio is

$$
D_{r}=\frac{S\left(L_{z}\right)}{S\left(L_{x}\right)}=5
$$

The Froude number should be the same for both the distorted physical model and the prototype

$$
\frac{V_{m}}{\sqrt{g h_{m}}}=\frac{V_{p}}{\sqrt{g h_{p}}}
$$

where $g$ is the gravitational acceleration, $V_{m}$ and $V_{p}$ are the flood wave propagation velocities in the model and the prototype, respectively. $h_{m}$ and $h_{p}$ are the water depths in the model and the prototype, respectively.

The velocity scale becomes

$$
S(V)=\frac{V_{m}}{V_{p}}=\sqrt{S\left(L_{z}\right)}=\frac{1}{5.48}
$$

The Strouhal numbers in the distorted physical model and the prototype should be equal to each other [14]

$$
\frac{V_{m} T_{m}}{L_{x m}}=\frac{V_{p} T_{p}}{L_{x p}}
$$

Eq. 4 can be expressed as

$$
S(V) S(T)=S\left(L_{x}\right)
$$

The time scale becomes

$$
S(T)=\frac{T_{m}}{T_{p}}=\frac{1}{27.4}
$$

According to Equation 3 and Equation 6,

\begin{tabular}{|c|c|c|}
\hline Characteristics & Prototype & Physical Model \\
\hline Crest length (m) & 426 & 2.84 \\
\hline Crest width (m) & 12 & 0.08 \\
\hline $\begin{array}{l}\text { Dam height from the } \\
\text { base }(m)\end{array}$ & 32 & 1.07 \\
\hline $\begin{array}{c}\text { Lake volume at } \\
\text { minimum level }\left(\mathrm{m}^{3}\right)\end{array}$ & 375000 & 0.556 \\
\hline $\begin{array}{c}\text { Lake volume at } \\
\text { maximum level }\left(\mathrm{m}^{3}\right)\end{array}$ & 8625000 & 12.778 \\
\hline $\begin{array}{l}\text { Lake volume at } \\
\text { normal level }\left(\mathrm{m}^{3}\right)\end{array}$ & 7950000 & 11.778 \\
\hline $\begin{array}{l}\text { Lake active volume } \\
\qquad\left(\mathrm{m}^{3}\right)\end{array}$ & 7575000 & 11.222 \\
\hline
\end{tabular}
$V_{p}=5.48 V_{m}$ and $T_{p}=27.4 T_{m}$, respectively.

Geometric characteristics of the prototype and the physical model are given in Table 1 .

Table 1. Geometric characteristics of the prototype and the physical model 


\subsection{Construction of the distorted physical model}

The distorted physical model was built in the open area of Hydraulics Laboratory of Dokuz Eylul University, Izmir. First, drainage pipes were placed in the experimental area. The bottom floor was leveled, filled with fine gravel and then compacted. The cross sections of the dam reservoir and the downstream area at every
$50 \mathrm{~m}$, were determined by using the related maps obtained from DSI (State Hydraulic Works) and were placed in the experimental area at the related locations. Brick walls around the reservoir were built and the reservoir was filled with granular material. Then concrete was poured over the surface and smoothed to replicate the topography of the dam reservoir. [9]. Final view of the dam reservoir is shown in Figure 2.

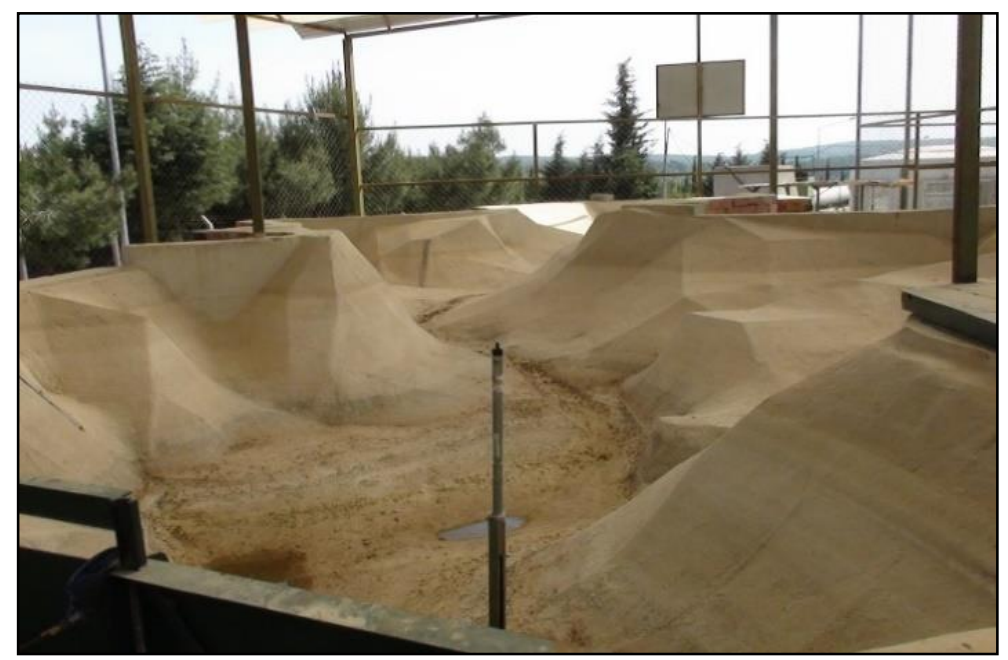

Figure 2. Final view of the reservoir

The same procedure was used in the construction of the downstream region of the distorted physical model. By the help of the maps obtained from Izmir Water and Sewage Department (IZSU), the residential area of Urkmez town was created by using wooden blocks that were cut into rectangular prismatic pieces based on the dimensions of the buildings. Seferihisar-Kuşadası highway passing through the town was also built by pouring mortar into the prepared mold. The picture of the distorted physical model of Urkmez dam with its reservoir and downstream region without vegetation is given in Figure 3.

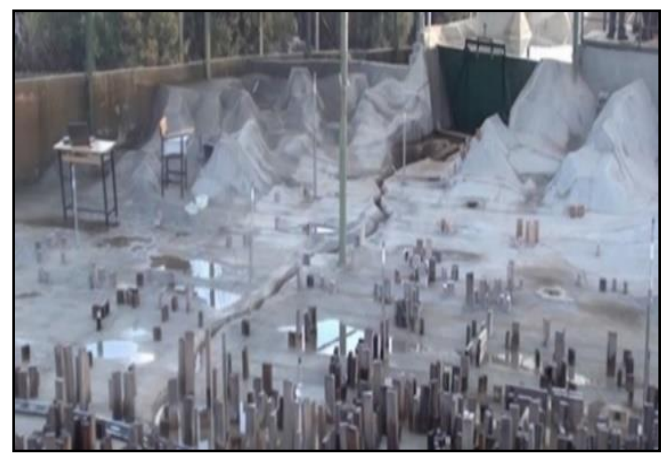

Figure 3. The distorted physical model without vegetation

The vegetation was created by using plastic brushes simulating the trees. The plastic brushes were installed at the upper upstream part of the downstream region. The used plastic brushes and their detailed dimensions are given in Figure 4 . 


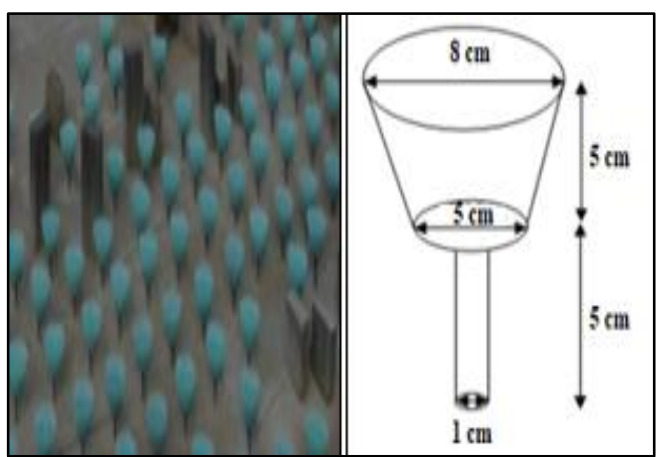

(a)

(b)

Figure 4. (a) The plastic brushes; (b) drawing of their detailed dimensions

The distorted physical model of Urkmez dam together with its reservoir and downstream region with partial vegetation is given in Figure 5.

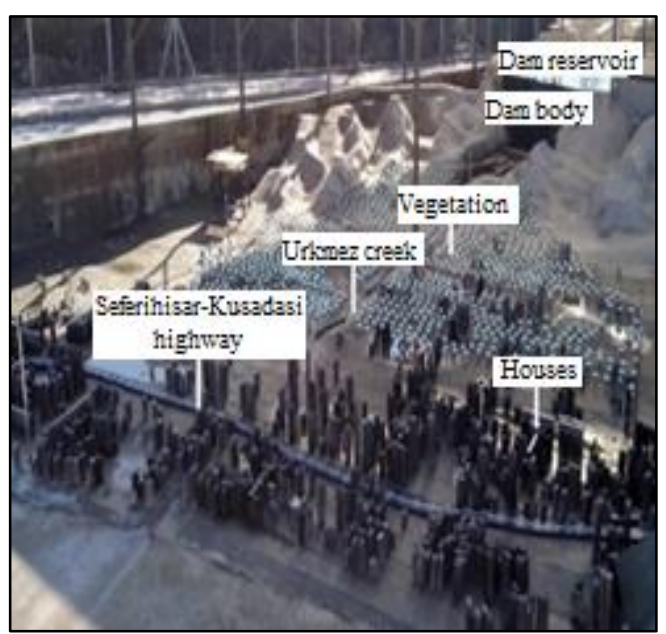

Figure 5. The distorted physical model with vegetation

\subsection{Measurment Method and Instruments}

Before the experiment was started, the dam gate was kept closed by means of a lock connected to electrical motor with hook, and the dam reservoir was filled with water (Figure 6).

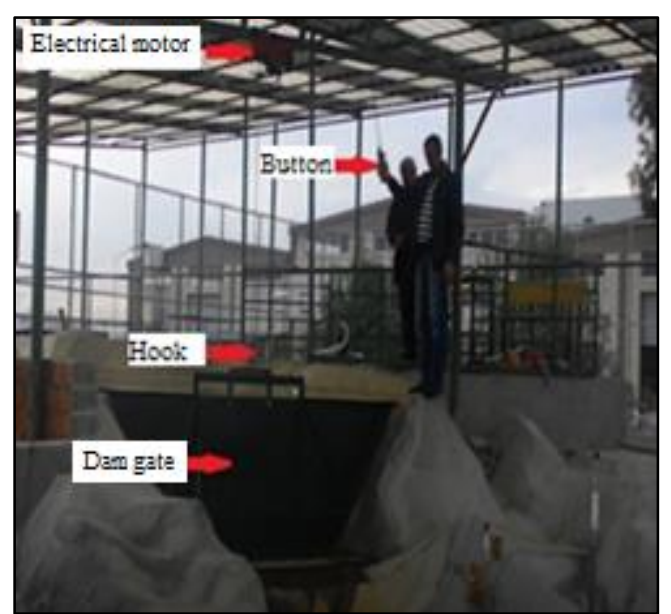

Figure 6. The dam gate before the experiment was started

When the experiment was started, by pushing the button connected to the electrical motor, the hook connected to the electrical motor was pulled up, lock was opened and the dam gate was overturned by the effect of water stored in the reservoir. Thus, the flood wave resulting from sudden dam failure was generated (Figure 7).

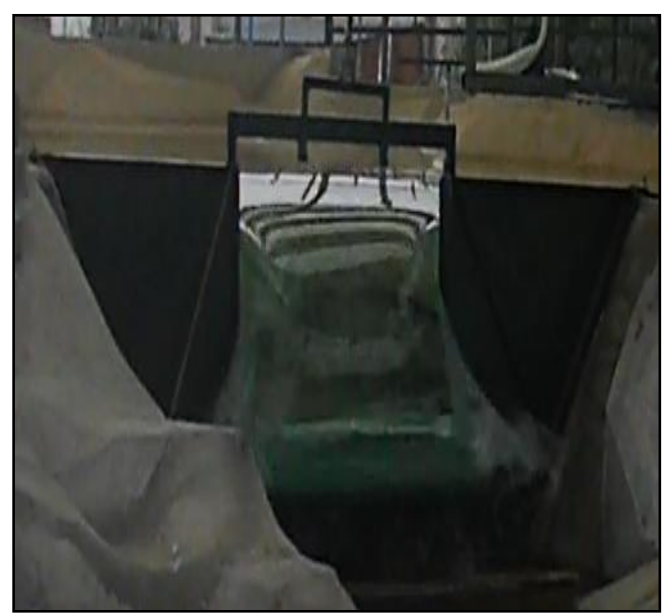

Figure 7. The overturned gate starting the experiment

Figure 8(a) shows the metal construction which simulates the dam body and Figure 8(b) illustrates its detailed dimensions. 


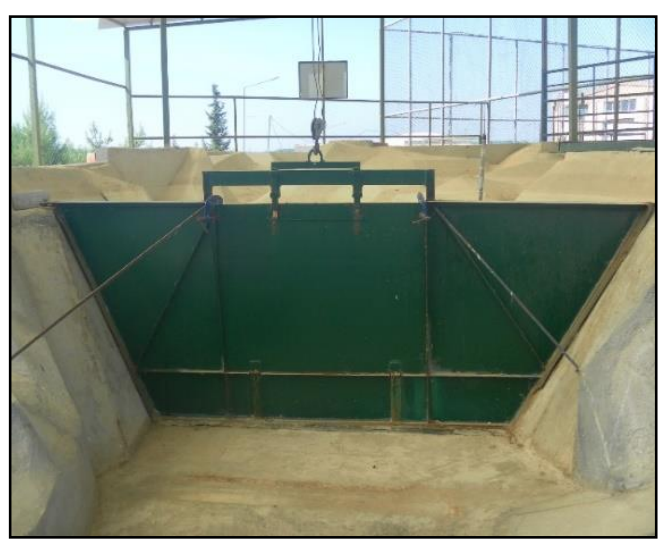

(a)

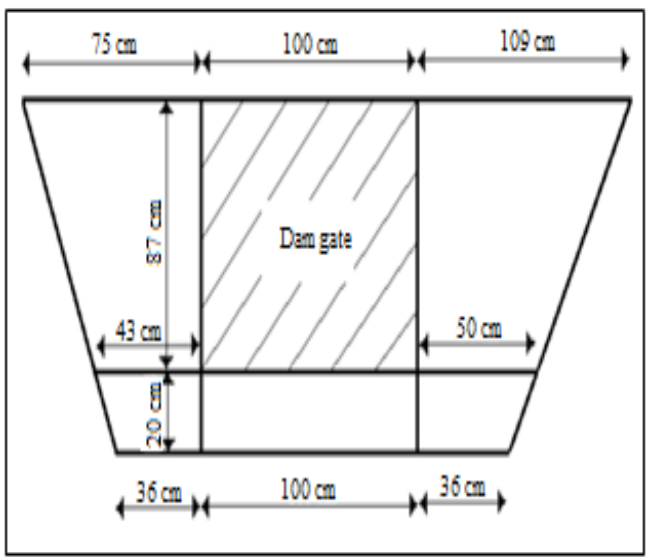

(b)

Figure 8. (a) The dam body; (b) its detailed dimensions

\subsection{1. e+ WATER L level meters}

Water depths were measured by means of this device which consists of e+ WATER L level sensors and e+ CONTROL. Before the experiment, the starting time is defined in the component e+ CONTROL which records all the measurements [15]. e+ WATER L level sensor and e+ CONTROL are given in Figure 9.

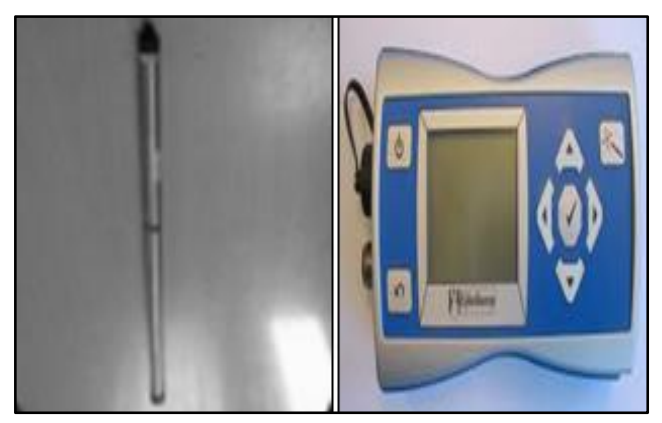

(a)

(b)

Figure 9. (a) e+ WATER L level sensor; (b) e+ CONTROL

\subsubsection{Ultrasonic velocity profiler (UVP)}

The time varied flow velocities were measured by UVP transducers placed in the hole at ground, UVP-DUO and remote computer (Figure 10).

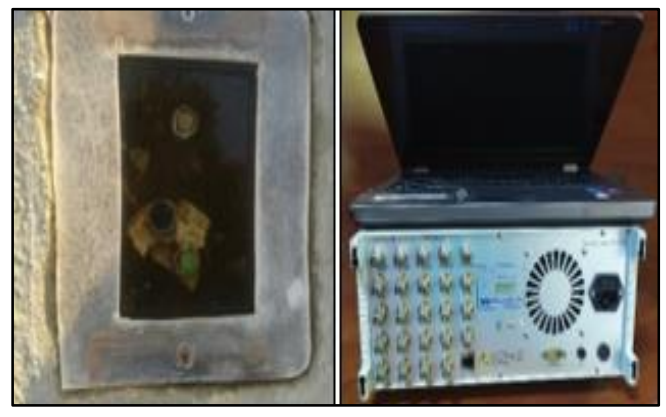

(a)

(b)

Figure 10. (a) UVP transducer; (b) UVP-DUO and remote computer

At the front panel of the UVP-DUO there is a power switch. On the back panel of the UVP-DUO there are connectors for connecting the transducers and there is an ethernet port for connecting the remote computer. All measurement functions are contained in the UVP-DUO unit, while the software with all its controlling and analysis functions is installed on the remote computer [16].

The level sensor (S1) was placed at the reservoir and near the dam body. Eight level sensors (S2, S3, S4, S5, S6, S7, S10, S11) were placed at various locations of the downstream region of the model. Five UVP transducers (T01, T03, T04, T06, T07) were located near the level sensors at the downstream region of the model (Figure 11). 


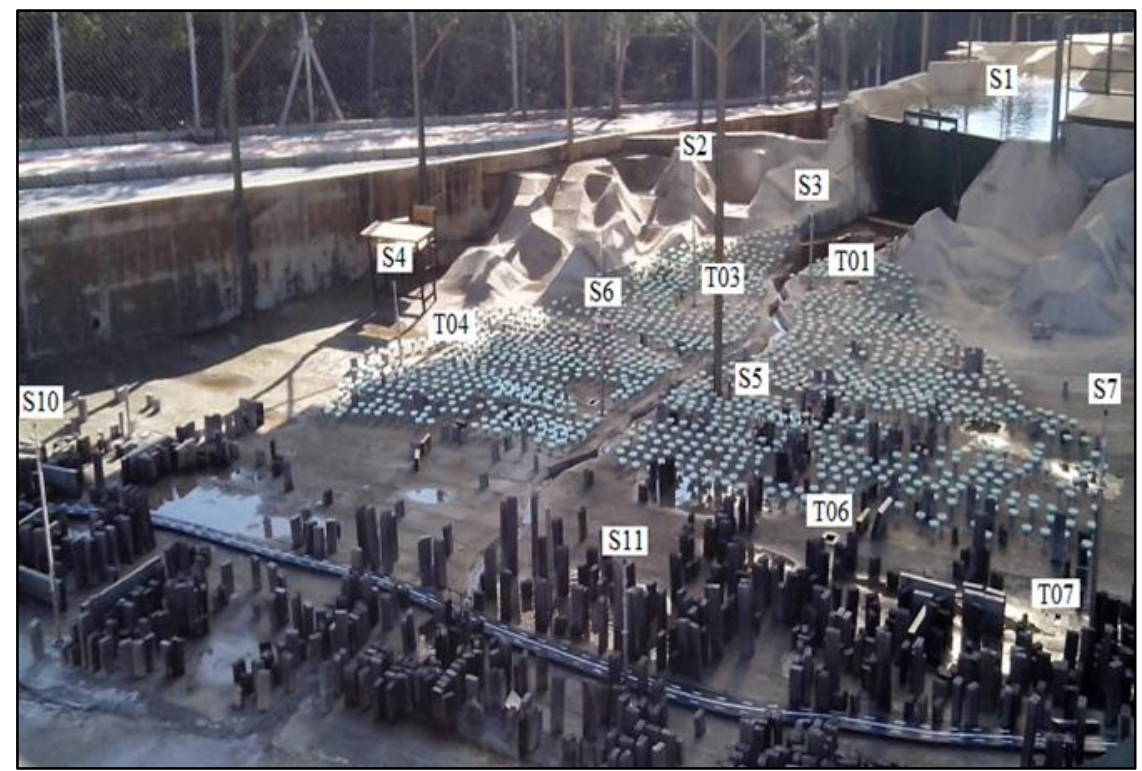

Figure 11. Locations of the level sensors and UVP transducers

The coordinates of the locations of the level sensors and the UVP transducers are given in Table 2.

Table 2 Locations of the measurement devices according to the chosen coordinate system and the values of $\alpha$ and $\beta$

\begin{tabular}{cccccc}
\hline Instrument & $\mathrm{X}(\mathrm{m})$ & $\mathrm{Y}(\mathrm{m})$ & $\mathrm{Z}(\mathrm{m})$ & $\begin{array}{c}\alpha \\
\left({ }^{\circ}\right)\end{array}$ & $\beta\left(^{\circ}\right)$ \\
\hline $\mathrm{S} 2$ & 8.05 & 4.55 & 0.30 & - & - \\
$\mathrm{S} 3$ & 6.71 & 3.56 & 0.37 & - & - \\
$\mathrm{S} 4$ & 11.53 & 7.51 & 0.13 & - & - \\
$\mathrm{S} 5$ & 5.81 & 9.10 & 0.10 & - & - \\
$\mathrm{S} 6$ & 8.06 & 7.77 & 0.16 & - & - \\
$\mathrm{S} 7$ & 2.89 & 10.04 & 0.07 & - & - \\
$\mathrm{S} 10$ & 10.64 & 13.18 & 0.04 & - & - \\
$\mathrm{S} 11$ & 6.02 & 11.94 & 0.06 & - & - \\
$\mathrm{T} 01$ & 6.56 & 3.18 & - & 7 & 14.3 \\
$\mathrm{~T} 03$ & 7.71 & 4.38 & - & 15 & 28.2 \\
$\mathrm{~T} 04$ & 11.21 & 7.35 & - & 15 & 42.7 \\
$\mathrm{~T} 06$ & 5.03 & 9.10 & - & 6 & 7.6 \\
$\mathrm{~T} 07$ & 3.15 & 9.71 & - & 1 & 19.9 \\
\hline
\end{tabular}

Note: $\alpha=$ angle with vertical; $\beta=$ angle between the line connected to the midpoint of the dam crest and Y-axis
Figure 12 depicts the orientation of the transducers, where the values of $\alpha$ and $\beta$ angles for each transducer are summarized in Table 2 . The seeding of the particles was not required because the physical model was constructed outside the laboratory and the water was full of small particles allowing the reflection of the ultrasonic waves.

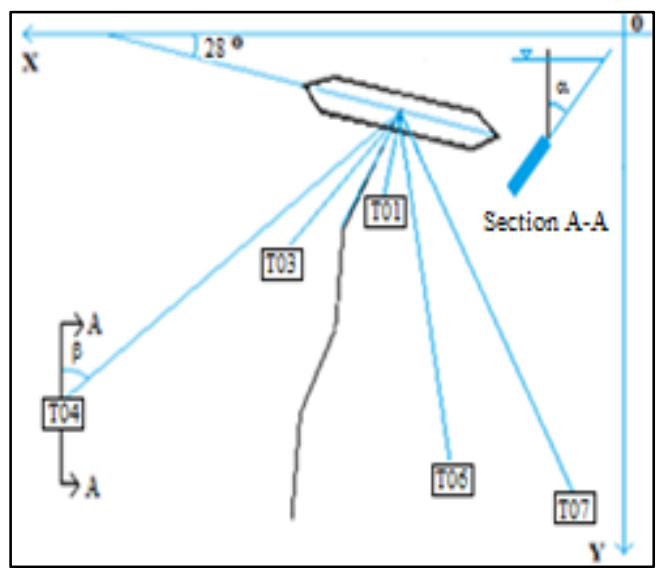

Figure 12. Orientation of UVP transducers

\subsubsection{High definition (HD) digital camera}

The time varied regions reached by the flood wave were recorded by HD camera located on the platform at the downstream end (Figure 13). 


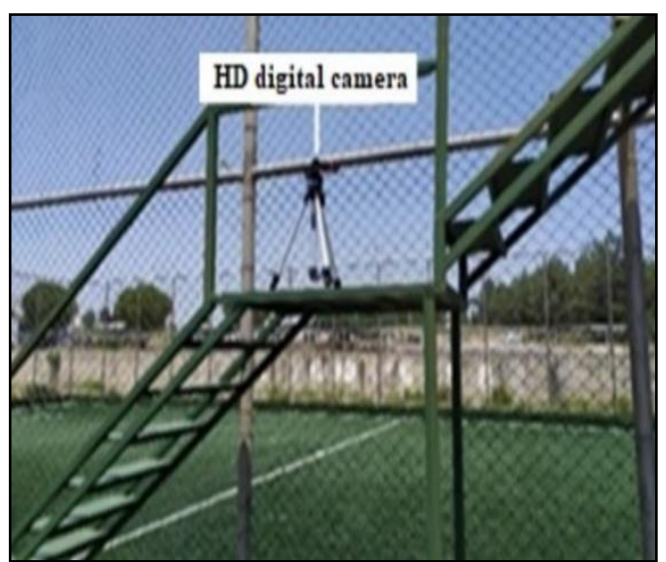

Figure 13. HD digital camera located on the platform at the downstream end

\section{Experimental Findings}

The experimental results presented in this paper correspond to the case at which the initial reservoir water depth was $96 \mathrm{~cm}$. The experiments were repeated three times to get the reliable results. The flow depth and velocity measurements presented and analyzed in the following sections are the averages of these three experiments. The so obtained results in the case of the existence of partial vegetation were compared to those obtained in the case of the absence of vegetation and also with the available experimental results obtained by Oguzhan and Aksoy [10] in the case of water depth of $98 \mathrm{~cm}$. As shown in Figure 14, Oguzhan and Aksoy [10] realized their experiments on the distorted physical model of dense vegetation. Besides, they used different experimental devices. Temporal variations of water depths were measured by using UltraLab ULS (Ultrasonic level sensor) 80-D device and USS20130 sensors. The temporal velocity values were determined using a Sontek MicroADV.

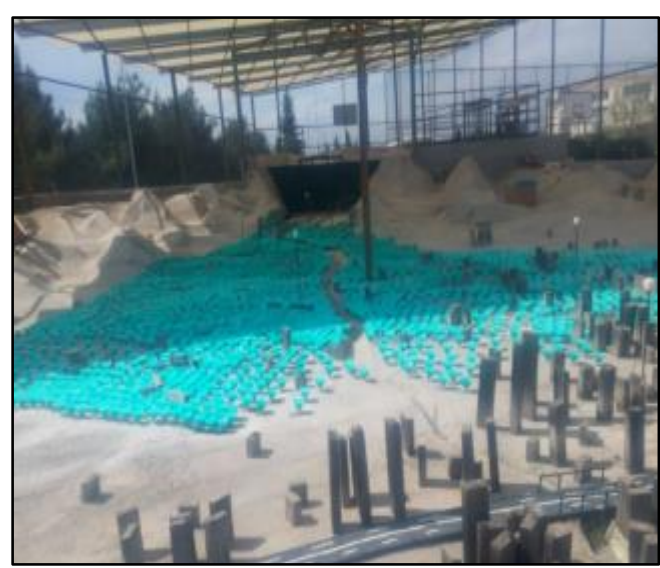

Figure 14. Physical model of Urkmez Dam Lake and downstream region with more dense vegetation [10]

\subsection{The model reservoir volume-water depth} curve

To obtain the model reservoir volume-water depth curve shown in Figure 15, the reservoir was filled with water at a constant discharge and the water depths in the reservoir were measured at specified time intervals. The volume of water in the reservoir was calculated by multiplying the measured discharge and the time interval. An analytical relation was investigated by using the measured values and the following equation was obtained from the regression analysis:

$$
\begin{aligned}
V= & 0.000006 h^{3}+0.0003 h^{2}+ \\
& 0.0112 h+0.0053
\end{aligned}
$$

In Equation 7, $V\left(\mathrm{~m}^{3}\right)$ is the volume of water in the reservoir and $h(\mathrm{~cm})$ is the water depth. The curve (shown in red) obtained from the measurement values and the curve (shown in black) obtained from the regression analysis (Equation 7) are given in Figure 15. 


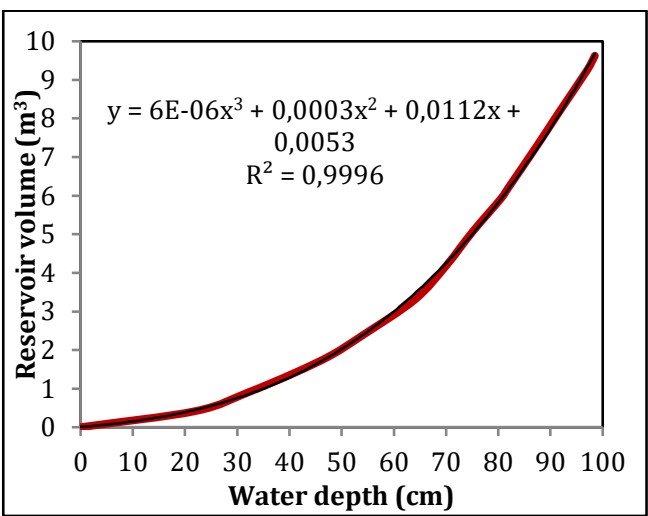

Figure 15. The model reservoir volume-water depth curve

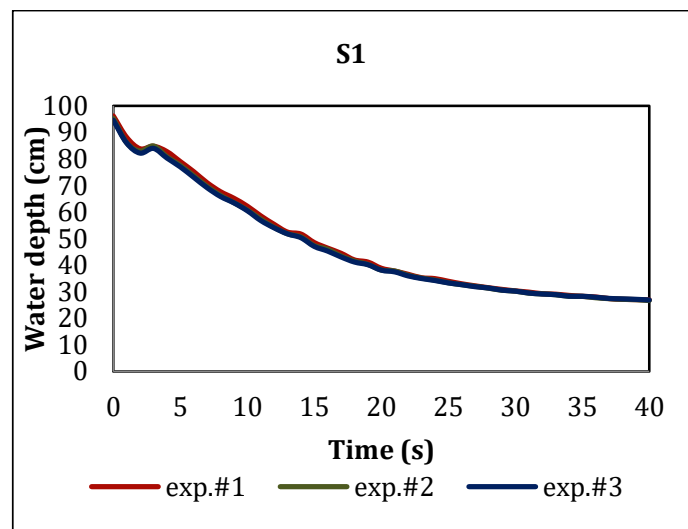

(a)

\subsection{The model flood hydrograph}

The dam gate was overturned by the effect of water stored in the reservoir, the decreases in the water depths of the reservoir were measured by the level sensor S1 at one-second intervals (Figure 16).

The measured water depths were converted to the volumes by using the Equation 7 . Then, the determined volume changes $(\Delta \mathrm{V})$ were divided by the relevant time intervals $(\Delta t=1 \mathrm{~s})$ and the averaged discharge values corresponding to that intervals were determined. The so obtained flood hydrograph is given in Figure 17.

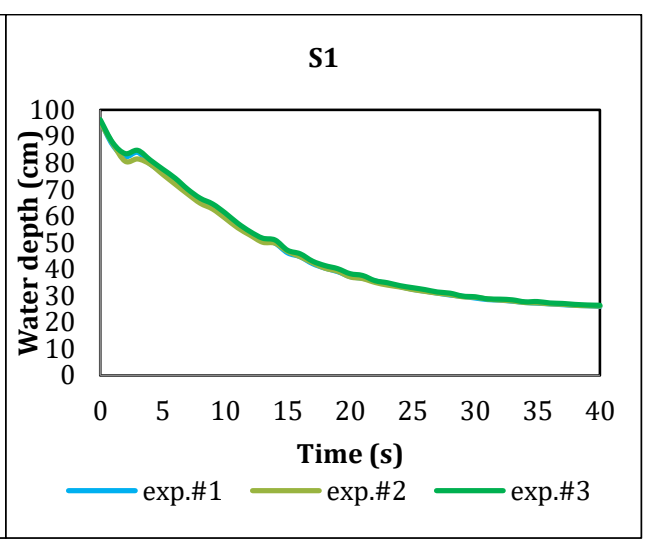

(b)

Figure 16. The water depths in the reservoir (a) without vegetation; (b) with vegetation

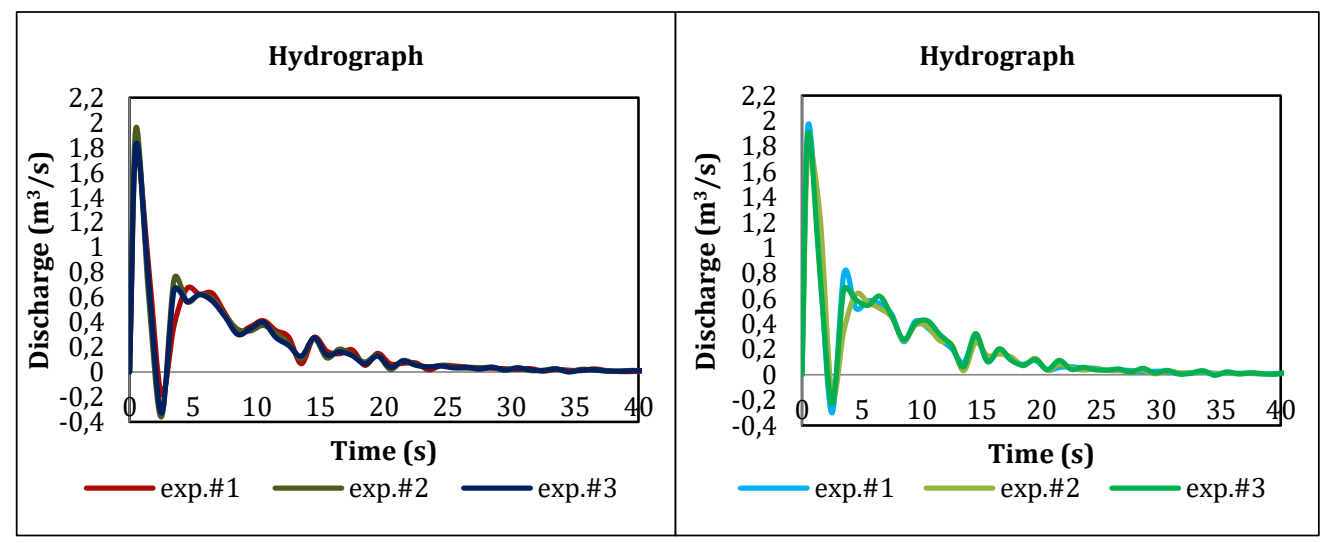

(a)

(b)

Figure 17. The flood hydrographs (a) without vegetation; (b) with vegetation 


\subsection{Wave propagation}

The flood wave propagation was recorded by a HD camera located at the downstream part.

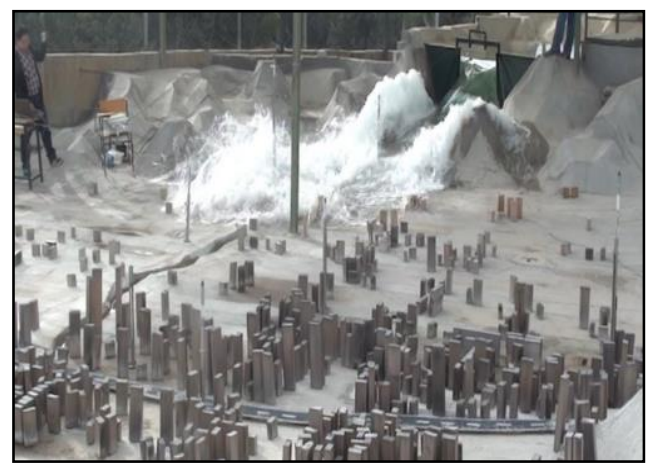

(a)
The regions reached by the flood wave in $2 \mathrm{~s}, 3 \mathrm{~s}$ and $6 \mathrm{~s}$ are shown in Figures 18, 19 and 20, respectively.

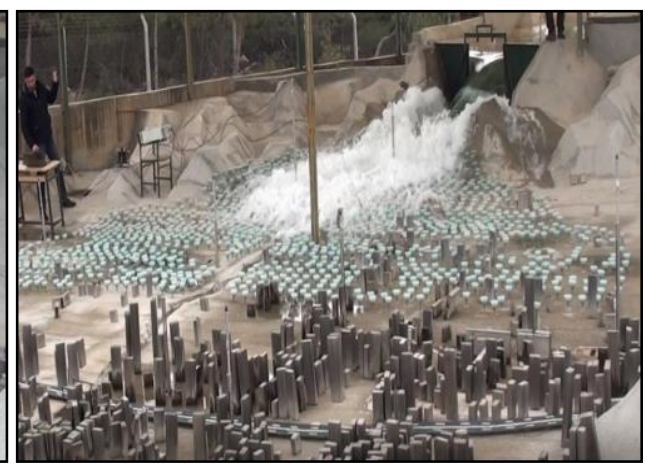

(b)

Figure 18. The regions reached by the flood wave in $2 \mathrm{~s}$ (a) without vegetation; (b) with vegetation

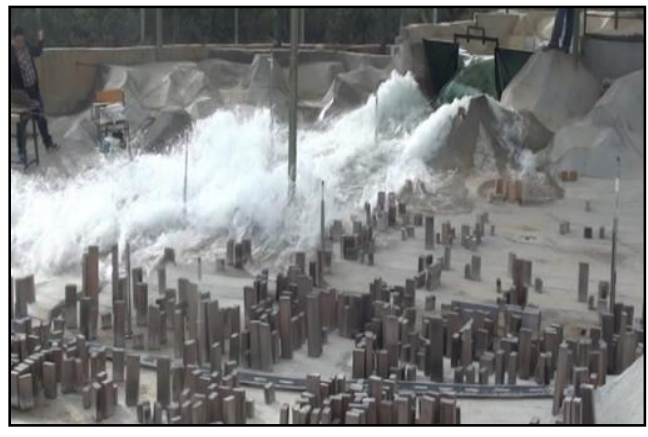

(a)

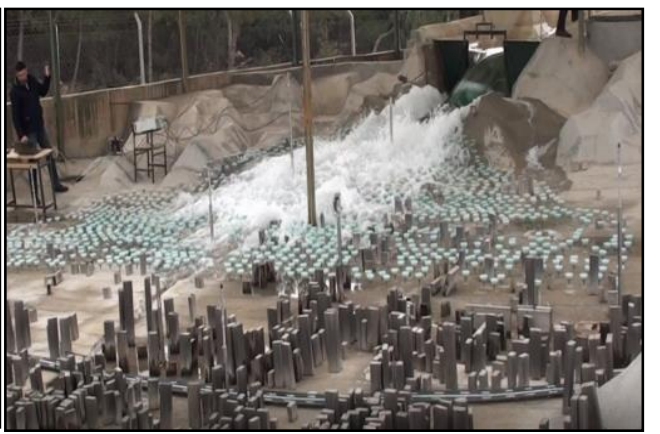

(b)

Figure 19. The regions reached by the flood wave in $3 \mathrm{~s}$ (a) without vegetation; (b) with vegetation

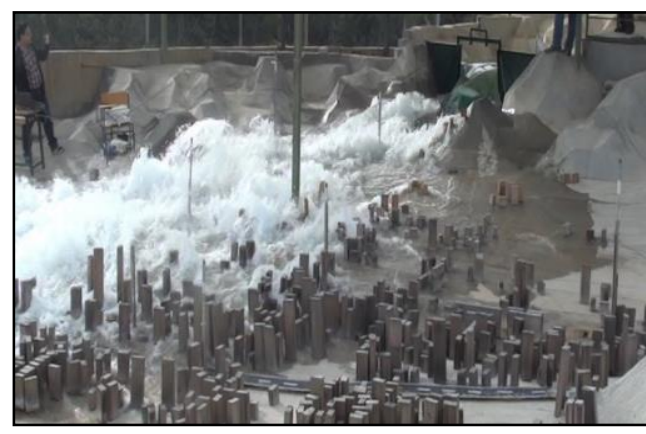

(a)

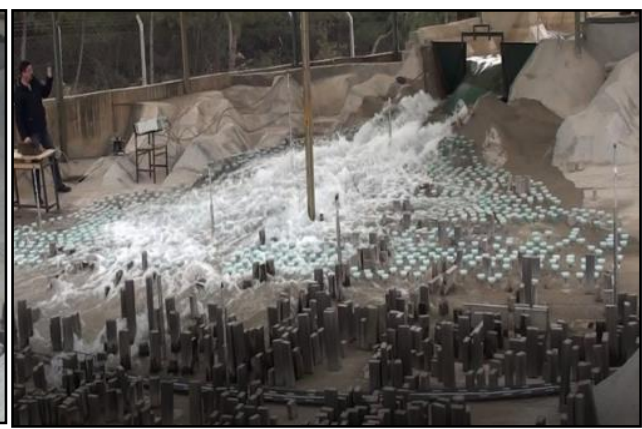

(b)

Figure 20. The regions reached by the flood wave in $6 \mathrm{~s}$ (a) without vegetation; (b) with vegetation

The flood wave arrival times to level sensors S3, S6, S5 and intersection points of Urkmez creek with highway and sea, in the absence and the presence of partial and dense vegetation cases are given in Table 3 . The values in bracket correspond to the prototype values obtained by conversion. 
DEÜ FMD 23(69), 803-821, 2021

Table 3. Flood wave arrival times to different regions

\begin{tabular}{cccc}
\hline \multirow{3}{*}{ Region } & \multicolumn{3}{c}{ Arrival Times } \\
\cline { 2 - 4 } & Experiment (s) [Prototype (min)] \\
\cline { 2 - 4 } & $1[0.46]$ & With Partial Vegetation & With Dense Vegetation [10] \\
\hline S3 & $3[1.37]$ & $1[0.46]$ & $1[0.46]$ \\
S6 & $4[1.83]$ & $4[1.83]$ & $5[2.28]$ \\
S5 & $4[1.83]$ & $6[2.74]$ & $8[3.65]$ \\
Highway & $6[2.74]$ & $6[2.74]$ & - \\
Sea & & $10[4.57]$ & - \\
\hline
\end{tabular}

\subsection{Flow depths}

Level sensors S2, S4, S6 and S10 are on the righthand side of the creek, while level sensors S3, S5, S7 and S11 are on the left-hand side, looking downward towards the sea from the dam body. S2 and S3 are located at very sparse residential areas close to the dam body. S4 and S6 are located at sparse residential areas. S5, S7, S10 and $\mathrm{S} 11$ are located at dense residential areas (Figure 11).
Figure 21 represents the measured flow depths on the right bank locations.

The flood wave arrival times to the right bank locations, in the absence and the presence of partial and dense vegetation are given in Table 4.

Maximum flow depths and elapsed times to reach maximum flow depths are listed in Table 5.

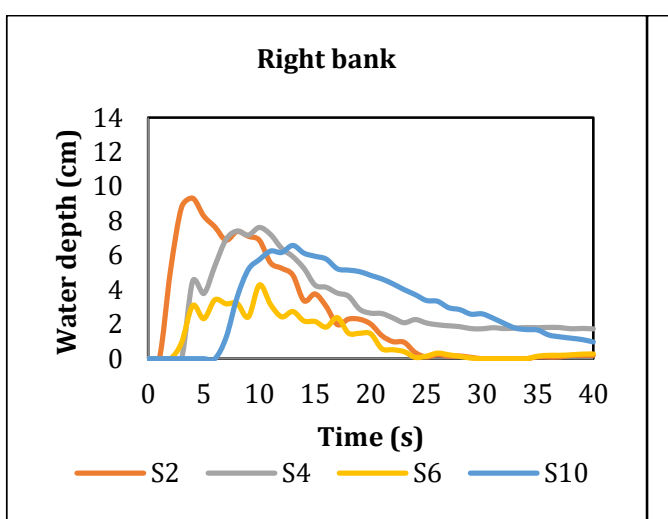

(a)

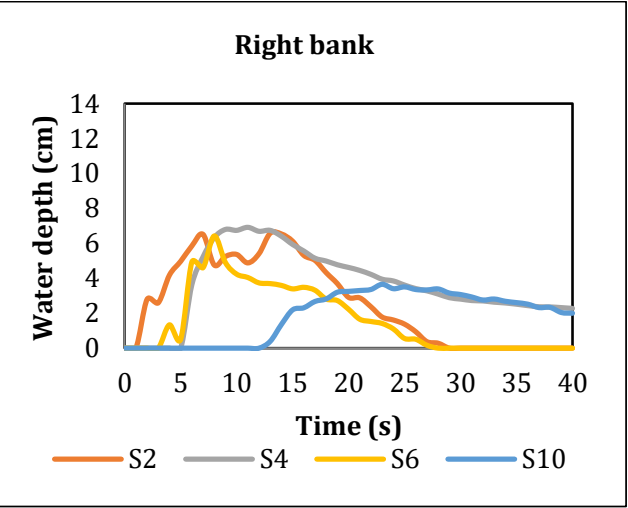

(b)

Figure 21. Comparison of flow depths at locations S2, S4, S6 and S10 (a) without vegetation; (b) with vegetation 
DEÜ FMD 23(69), 803-821, 2021

Table 4. Flood wave arrival times at the right bank locations

\begin{tabular}{cccc}
\hline \multirow{3}{*}{ Region } & \multicolumn{3}{c}{ Arrival Times } \\
\cline { 2 - 4 } & Without Vegetation & With Partial Vegetation & With Dense Vegetation [10] \\
\cline { 2 - 4 } & $2[0.91]$ & $2[0.91]$ & $2[0.91]$ \\
S2 & $4[1.83]$ & $6[2.74]$ & $7[3.20]$ \\
S4 & $3[1.37]$ & $4[1.83]$ & $5[2.28]$ \\
S10 & $7[3.20]$ & $13[5.94]$ & - \\
\hline
\end{tabular}

Table 5. Maximum flow depths and elapsed times to reach maximum flow depths on the right bank locations

\begin{tabular}{|c|c|c|c|c|c|c|}
\hline \multirow[t]{4}{*}{ Region } & \multicolumn{3}{|c|}{ Maximum Flow Depths } & \multicolumn{3}{|c|}{ Elapsed Times } \\
\hline & \multirow{2}{*}{\multicolumn{3}{|c|}{$\begin{array}{l}\text { Experiment }(\mathrm{cm}) \\
{[\text { Prototype }(\mathrm{m})]}\end{array}$}} & \multirow{2}{*}{\multicolumn{3}{|c|}{$\begin{array}{c}\text { Experiment (s) } \\
\text { [Prototype (min)] }\end{array}$}} \\
\hline & & & & & & \\
\hline & $\begin{array}{l}\text { Without } \\
\text { Vegetation }\end{array}$ & $\begin{array}{l}\text { With Partial } \\
\text { Vegetation }\end{array}$ & $\begin{array}{c}\text { With Dense } \\
\text { Vegetation } \\
{[10]}\end{array}$ & $\begin{array}{c}\text { Without } \\
\text { Vegetation }\end{array}$ & $\begin{array}{l}\text { With Partial } \\
\text { Vegetation }\end{array}$ & $\begin{array}{c}\text { With Dense } \\
\text { Vegetation } \\
{[10]}\end{array}$ \\
\hline S2 & $9.30[2.79]$ & 6.60 [1.98] & 28.75 [8.63] & $4[1.83]$ & $13[5.94]$ & $6[2.74]$ \\
\hline S4 & $7.60[2.28]$ & $6.90[2.07]$ & $1.24[0.37]$ & $10[4.57]$ & $11[5.02]$ & $10[4.57]$ \\
\hline S6 & $4.30[1.29]$ & $6.40[1.92]$ & $5.21[1.56]$ & $10[4.57]$ & $8[3.65]$ & $5[2.28]$ \\
\hline S10 & $6.60[1.98]$ & $3.70[1.11]$ & - & 13 [5.94] & $23[10.50]$ & - \\
\hline
\end{tabular}

Figure 22 represents the measured flow depths on the left bank locations.

The flood wave arrival times to the left bank locations, in the absence and the presence of partial and dense vegetation are given in Table 6.
Maximum flow depths and elapsed times to reach maximum flow depths are listed in Table 7.

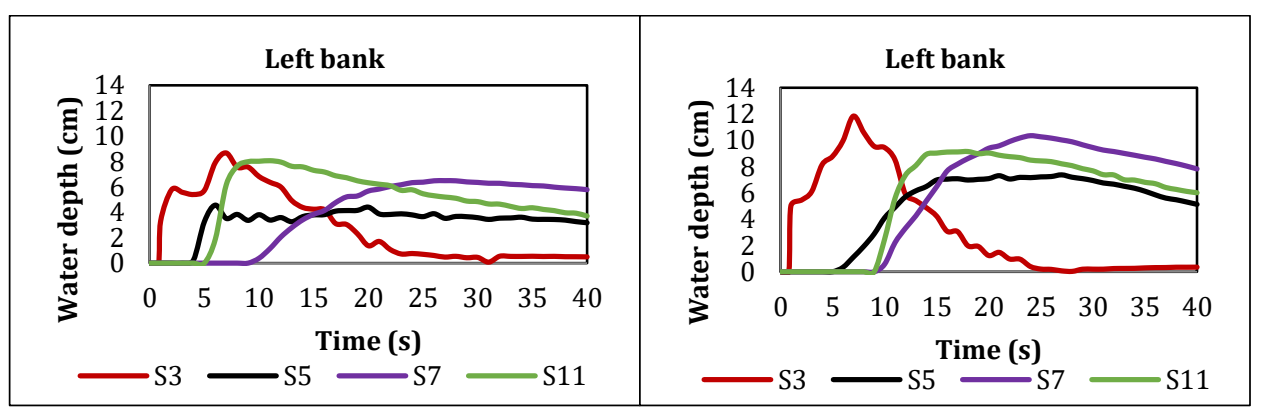

(a)

(b)

Figure 22. Comparison of flow depths at locations S3, S5, S7 and S11 (a) without vegetation; (b) with vegetation 
DEÜ FMD 23(69), 803-821, 2021

Table 6 Flood wave arrival times at the left bank locations

\begin{tabular}{cccc}
\hline \multirow{3}{*}{ Region } & \multicolumn{3}{c}{ Arrival Times } \\
\cline { 2 - 4 } & Wxperiment (s) [Prototype (min)] \\
\cline { 2 - 4 } & $1[0.46]$ & With Partial Vegetation & With Dense Vegetation [10] \\
\hline S3 & $4[1.83]$ & $1[0.46]$ & $1[0.46]$ \\
S5 & $10[4.57]$ & $6[2.74]$ & $8[3.65]$ \\
S7 & $6[2.74]$ & $10[4.57]$ & - \\
S11 & & $10[4.57]$ & - \\
\hline
\end{tabular}

Table 7 Maximum flow depths and elapsed times to reach maximum flow depths on the left bank locations

\begin{tabular}{|c|c|c|c|c|c|c|}
\hline \multirow[t]{4}{*}{ Region } & \multicolumn{3}{|c|}{ Maximum Flow Depths } & \multicolumn{3}{|c|}{ Elapsed Times } \\
\hline & \multicolumn{3}{|c|}{ Experiment $(\mathrm{cm})$} & \multicolumn{3}{|c|}{ Experiment (s) } \\
\hline & \multicolumn{3}{|c|}{ [Prototype (m)] } & \multicolumn{3}{|c|}{ [Prototype (min)] } \\
\hline & $\begin{array}{c}\text { Without } \\
\text { Vegetation }\end{array}$ & $\begin{array}{l}\text { With Partial } \\
\text { Vegetation }\end{array}$ & $\begin{array}{c}\text { With Dense } \\
\text { Vegetation } \\
{[10]}\end{array}$ & $\begin{array}{c}\text { Without } \\
\text { Vegetation }\end{array}$ & $\begin{array}{l}\text { With Partial } \\
\text { Vegetation }\end{array}$ & $\begin{array}{c}\text { With Dense } \\
\text { Vegetation } \\
{[10]}\end{array}$ \\
\hline S3 & $8.70[2.61]$ & $11.80[3.54]$ & $10.52[3.16]$ & $7[3.20]$ & $7[3.20]$ & $1[0.46]$ \\
\hline S5 & $4.60[1.38]$ & 7.30 [2.19] & $2.60[0.78]$ & $6[2.74]$ & 21 [9.59] & $15[6.85]$ \\
\hline S7 & $6.50[1.95]$ & $10.40[3.12]$ & - & 26 [11.87] & $24[10.96]$ & - \\
\hline S11 & $8.10[2.43]$ & $9.20[2.76]$ & - & $11[5.02]$ & 18 [8.22] & - \\
\hline
\end{tabular}

\subsection{Flow velocities}

\subsubsection{Depth averaged velocities}

Transducers T03 and T04 are on the right-hand side of the creek near the level sensors S2 and S4, respectively. Transducers T01, T06 and T07 are on the left-hand side of the creek near the level sensors S3, S5 and S7, respectively (Figure 11).
Figure 23 represents depth averaged flow velocities measured in the related UVP direction, on the right bank locations.

Maximum flow velocities and elapsed times to reach maximum flow velocities are listed in Table 8. 
DEÜ FMD 23(69), 803-821, 2021

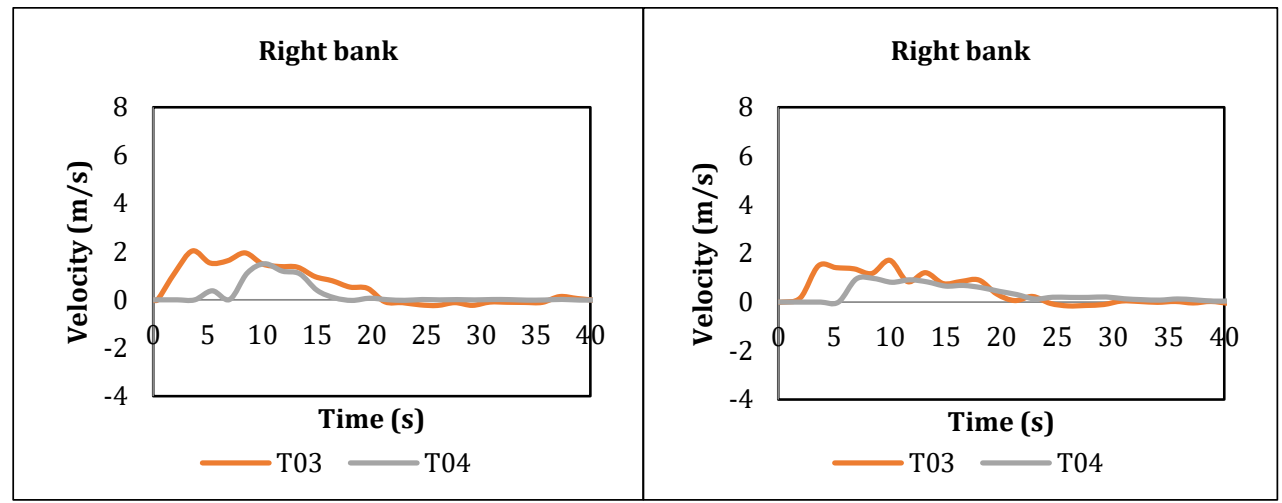

(a)

(b)

Figure 23. Comparison of flow velocities at locations T03 and T04 (a) without vegetation; (b) with vegetation

Table 8. Maximum flow velocities and elapsed times to reach maximum flow velocities at the right bank locations

\begin{tabular}{|c|c|c|c|c|}
\hline \multirow[t]{4}{*}{ Region } & \multicolumn{2}{|c|}{ Maximum Flow Velocities } & \multicolumn{2}{|c|}{ Elapsed Times } \\
\hline & \multicolumn{2}{|c|}{ Experiment (m/s) } & \multicolumn{2}{|c|}{ Experiment (s) } \\
\hline & \multicolumn{2}{|c|}{ [Prototype $(\mathrm{m} / \mathrm{s})]$} & \multicolumn{2}{|c|}{ [Prototype (min)] } \\
\hline & Without Vegetation & $\begin{array}{l}\text { With Partial } \\
\text { Vegetation }\end{array}$ & Without Vegetation & $\begin{array}{l}\text { With Partial } \\
\text { Vegetation }\end{array}$ \\
\hline T03 & $2.03[11.12]$ & $1.72[9.43]$ & $3.60[1.64]$ & $10[4.57]$ \\
\hline T04 & $1.50[8.22]$ & $0.97[5.32]$ & $10.20[4.66]$ & 8.6 [3.93] \\
\hline
\end{tabular}

Figure 24 represents depth averaged flow velocities measured in the related UVP direction, at the left bank locations.
Maximum flow velocities and elapsed times to reach maximum flow velocities are listed in Table 9.

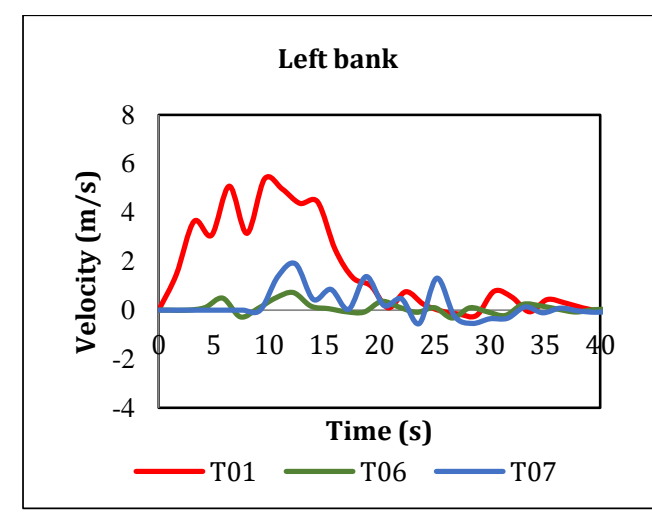

(a)

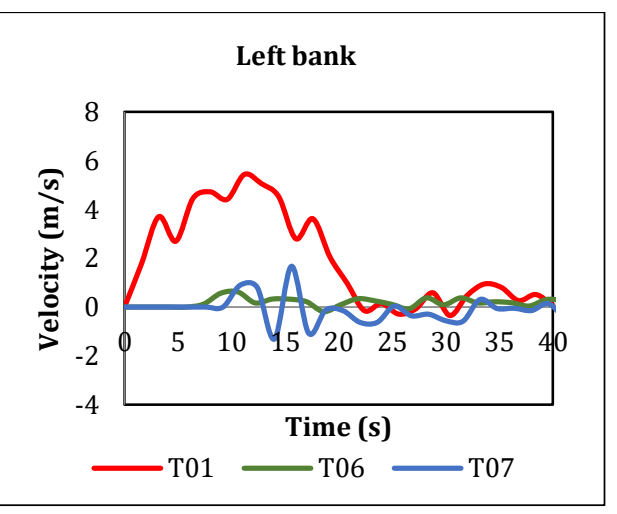

(b)

Figure 24. Comparison of flow velocities at locations T01, T06 and T07 (a) without vegetation; (b) with vegetation 
DEÜ FMD 23(69), 803-821, 2021

Table 9 Maximum flow velocities and elapsed times to reach maximum flow velocities on the left bank locations

\begin{tabular}{|c|c|c|c|c|}
\hline \multirow[t]{4}{*}{ Region } & \multicolumn{2}{|c|}{ Maximum Flow Velocities } & \multicolumn{2}{|c|}{ Elapsed Times } \\
\hline & \multicolumn{2}{|c|}{ Experiment (m/s) } & \multicolumn{2}{|c|}{ Experiment (s) } \\
\hline & \multicolumn{2}{|c|}{ [Prototype (m/s)] } & \multicolumn{2}{|c|}{ [Prototype (min)] } \\
\hline & Without Vegetation & $\begin{array}{l}\text { With Partial } \\
\text { Vegetation }\end{array}$ & Without Vegetation & $\begin{array}{l}\text { With Partial } \\
\text { Vegetation }\end{array}$ \\
\hline $\mathrm{T} 01$ & 5.38 [29.48] & $5.44[29.81]$ & $9.60[4.38]$ & $11.20[5.11]$ \\
\hline T06 & $0.72[3.95]$ & $0.62[3.40]$ & $12.20[5.57]$ & $10.60[4.84]$ \\
\hline T07 & $1.90[10.41]$ & $1.67[9.15]$ & $12.40[5.66]$ & $15.60[7.12]$ \\
\hline
\end{tabular}

\subsubsection{Velocity profiles at various times}

Velocity profiles obtained from T01, T03, T04, T06 and T07 at times corresponding to the

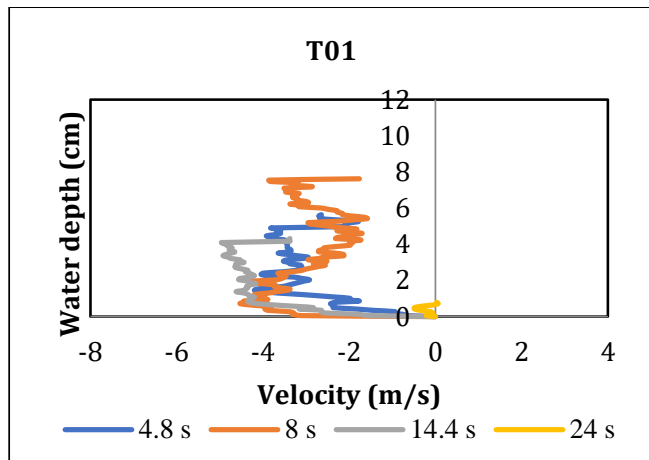

(a) approximately midpoint of the rising limb, the crest, the midpoint of the falling limb and the end of the water depth curve are given in Figures 25, $26,27,28$ and 29 , respectively.

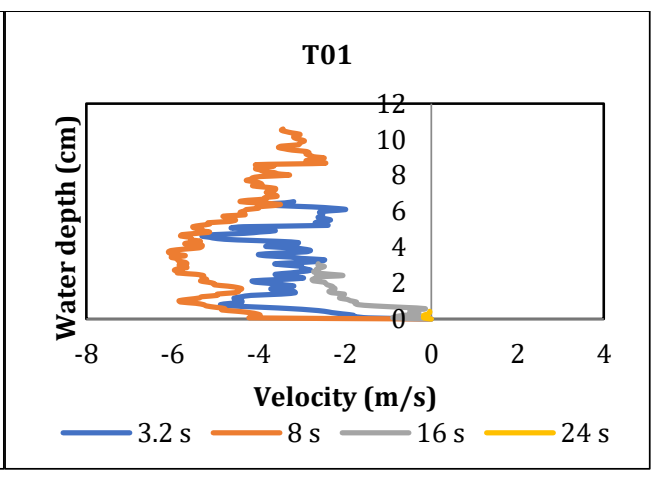

(b)

Figure 25. Velocity profiles obtained from the transducer $\mathrm{T} 01$ at various times (a) without vegetation; (b) with vegetation

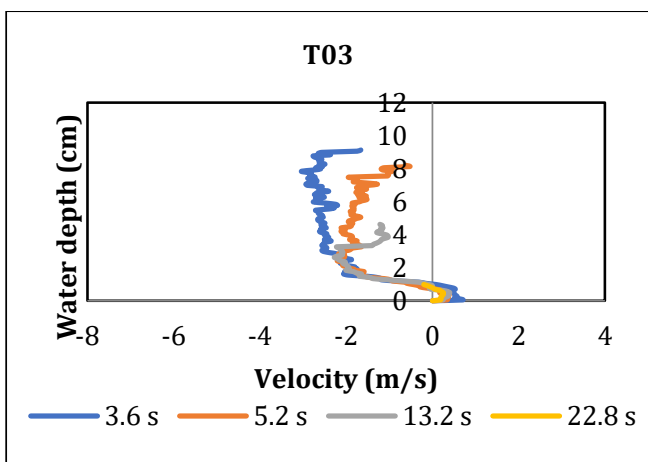

(a)

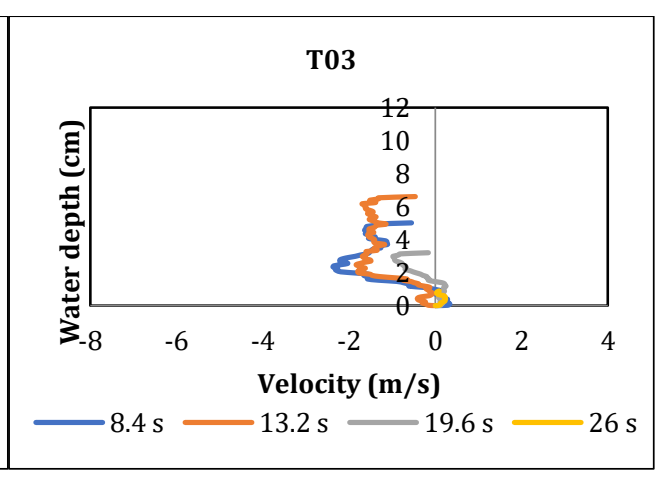

(b)

Figure 26. Velocity profiles obtained from the transducer T03 at various times (a) without vegetation; (b) with vegetation 
DEÜ FMD 23(69), 803-821, 2021

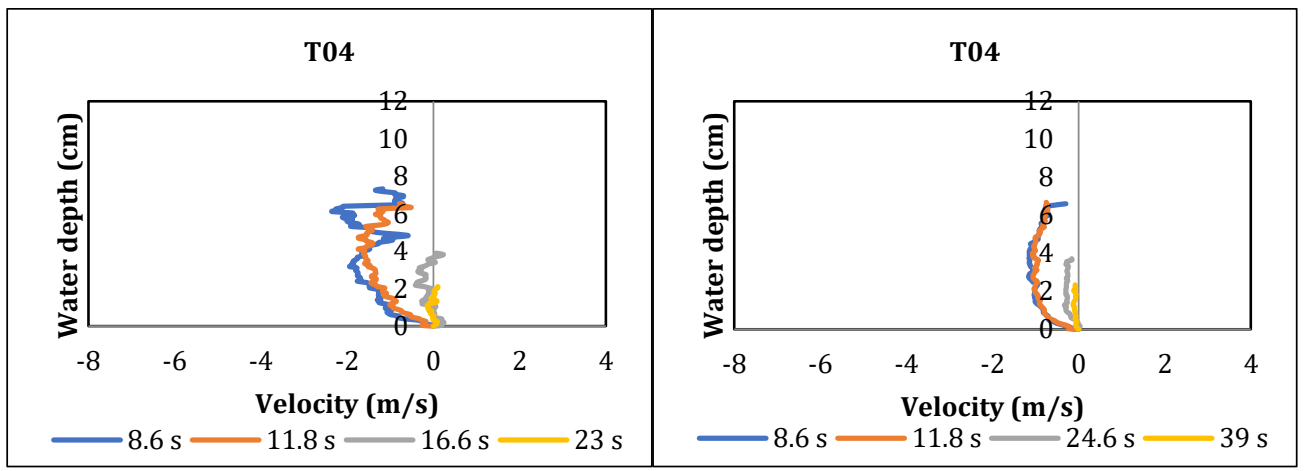

(a)

(b)

Figure 27. Velocity profiles obtained from the transducer T04 at various times (a) without vegetation; (b) with vegetation

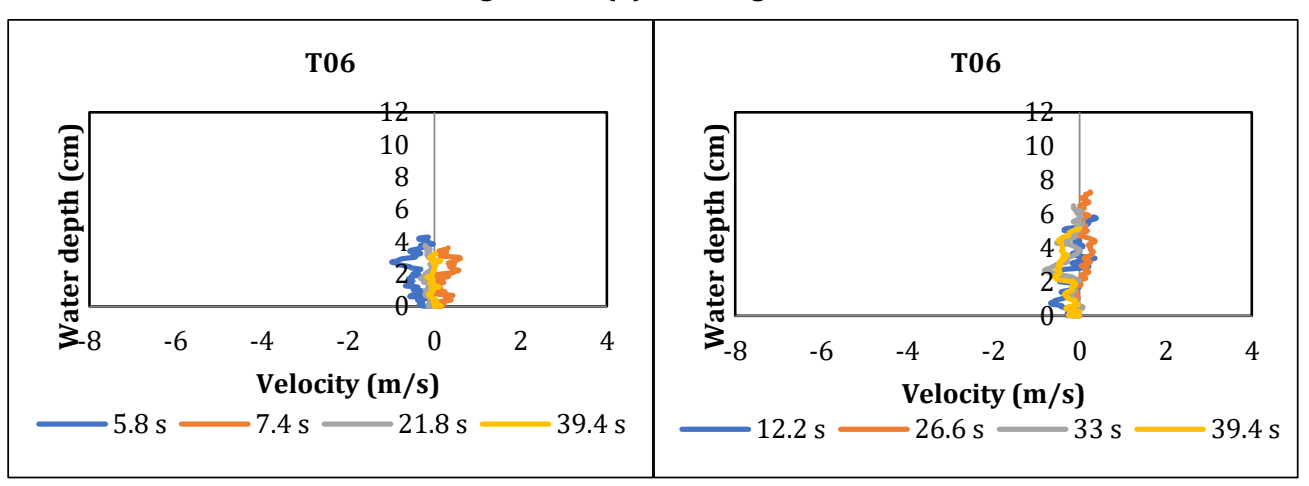

(a)

(b)

Figure 28. Velocity profiles obtained from the transducer T06 at various times (a) without vegetation; (b) with vegetation

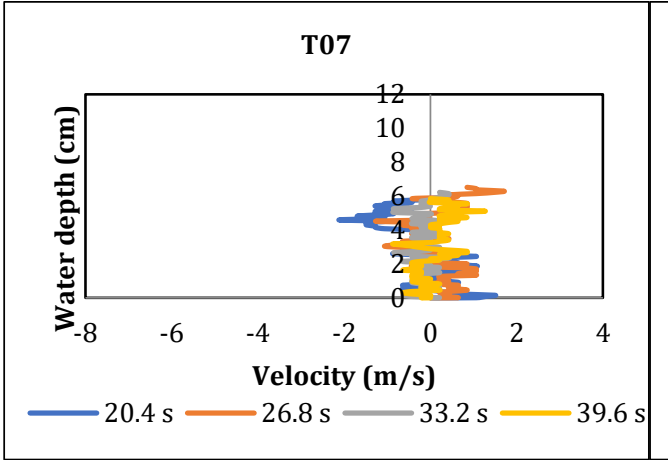

(a)

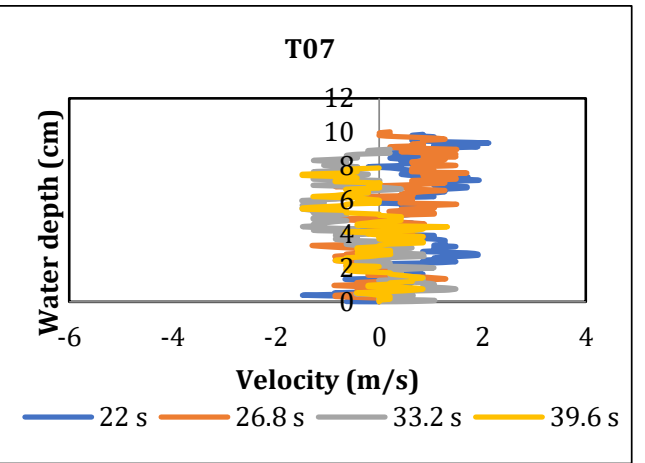

(b)

Figure 29. Velocity profiles obtained from the transducer T07 at various times (a) without vegetation; (b) with vegetation 
From the Figure 25, it was found that the velocity values increased during the rising limb and decreased during the falling limb of the water depth curve in the region close to the dam of the left bank. According to the Figures 26 and 27, the velocity values decreased during all the stages of the water depth curve in the regions close to the dam and in the middle part (sparse residential area) of the right bank, respectively. From the Figure 28 , it is observed that the velocity values decreased during the rising limb and increased during the falling limb of the water depth curve in the middle part of the resindential area of the left bank. According to the Figure 29, the magnitudes of the velocities are found to be close to each other but their directions were different during the rising limb and the falling limb of the water depth curve at the far left of the residential area of the left bank.

\section{Discussion and Conclusion}

The presence of partial vegetation influenced the propagation times of the flood wave mainly in the middle and end parts of Urkmez village. The experimental results revealed that, in such a dam failure, the flood arrives at the sea in $6 \mathrm{~s}$ in the absence of vegetation, while in $10 \mathrm{~s}$ in the presence of vegetation. These values correspond to $2.74 \mathrm{~min}$ and $4.57 \mathrm{~min}$, respectively in the prototype. The existence of partial vegetation resulted in decrease in flood propagation velocities consequently delay in arrival times mainly in the dense residential area, as expected (Table 3).

From the Tables 3, 4 and 6, the arrival times of the flood wave at locations close to dam (S2 and S3) are the same in the case of partial and dense vegetation. Delay in arrival times at other locations (S4, S5 and S6) is greater in the case of dense vegetation.

In the presence of partial vegetation, it was observed that the maximum water depths increase at the left bank and decrease at the right bank, except at level meter S6 which is very close to the creek (Tables 5 and 7).

According to the Tables 5 and 7, a common tendency concerning the influence of partial or dense vegetation on the maximum water depths and elapsed times to reach maximum depths was not observed.

The depth averaged velocity profiles drawn for certain times were also found to be significantly effected from the presence of the partial vegetation. It was observed that the maximum depth averaged velocities were decreased in the sparse and dense residential areas (Tables 8 and 9).

The influence of partial or dense vegetation on maximum flow velocities and elapsed times to reach maximum flow velocities (Tables 8 and 9) could not be determined since these values are not given in Oguzhan and Aksoy [10] where only the point velocity along the UVP direction at the point $5.3 \mathrm{~cm}$ from the bottom is provided. When this component is compared it was found that this velocity component decreased more in the case of dense vegetation.

It was observed that the existence of the vegetation changed considerably the local velocities during rising and recession stages of the water depth (Figures 25, 26, 27, 28 and 29).

It was revealed that, even in the case of partial vegetation, the order of magnitude of the prototype velocities was high and such velocities could cause serious damage mainly in the buildings close to the dam body. Because the presence of vegetation caused a decrease in flood propagation velocities in the sparse and dense residential areas, it would reduce the damages on the buildings in these areas.

\section{Acknowledgment}

The experiments were performed on the distorted physical model designed and built in the scope of the project number 110M240 supported by the Scientific and Technological Research Council of Turkey (TUBITAK). The authors thank TUBITAK for its financial support.

\section{References}

[1] Singh, V.P. 1996. Dam Breach Modeling Technology. Boston: Kluwer Academic Publishers. Dordrecht, 1996.

[2] Chen, X., Chen, Q., Zhan, J., Liu, D. 2016. Numerical Simulations of Wave Propagation over a Vegetated Platform, Coastal Engineering, 110, pp. 64-75. DOI: 10.1016/j.coastaleng.2016.01.003

[3] Yang, K., Cao, S., Knight, D.W. 2007. Flow Patterns in Compound Channels with Vegetated Floodplain, Journal of Hydraulic Engineering, 133(2), pp. 148159, DOI: 10.1061/(ASCE)07339429(2007)133:2(148)

[4] Chen, G., Huai, W.-X., Han, J., Zhao, M.-D. 2010. Flow Structure in Partially Vegetated Rectangular Channels, Journal of Hydrodynamics, 22(4), pp. 590597. DOI: 10.1016/S1001-6058(09)60092-5 
[5] Zhang, M., Hao, Z., Zhang, Y., Wu, W. 2013. Numerical Simulation of Solitary and Random Wave Propagation Through Vegetation Based on VOF Method, Acta Oceanol. Sin., 32(7), pp. 38-46. DOI: 10.1007/s13131-013-0330-4

[6] Zhang, M., Xu, Y., Li, J., Qiao, H., Zhang, H. 2016. Interactions Study of Hydrodynamic-MorphologyVegetation for Dam-Break Flows, Hindawi Mathematical Problems in Engineering, pp. 1-12 DOI: $10.1155 / 2016 / 3818591$

[7] He, Z., Wu, T., Weng, H., Hu, P., Wu, G. 2017. Numerical Simulation of Dam-Break Flow and Bed Change Considering the Vegetation Effects, International Journal of Sediment Research, 32(1), pp. 105-120. DOI: 10.1016/j.ijsrc.2015.04.004

[8] Li, W., Wang, D., Jiao, J., Yang, K. 2019. Effects of Vegetation Patch Density on Flow Velocity. Characteristics in an Open Channel, Journal of Hydrodynamics, 31, pp. 1052-1059. DOI: 10.1007/s42241-018-0086-6

[9] Güney, M.S., Tayfur, G., Bombar, G., Elci, S. 2014 Distorted Physical Model to Study Sudden Partial Dam Break Flows in an Urban Area, Journal of Hydraulic Engineering, 140(11), pp. 1-11. DOI:10.1061/(ASCE)HY.1943-7900.0000926

[10] Oguzhan, S., Aksoy, A.O. 2020. Experimental Investigation of the Effect of Vegetation on Dam Break Flood Waves, Journal of Hydrology and Hydromechanics, 68, 2020, 3, pp. 231-241. DOI: 10.2478/johh-2020-0026

[11] Sevinc, E., Guney, M.S. 2018. Time Varied Water Depths and Local Velocities Resulting from Flood Wave Propagation in the Distorted Physical Model of Ürkmez Dam in the case of Partial Vegetation. 5th International Symposium on Dam Safety, 27-31 October, Istanbul, 1027-1038.

[12] TUBITAK project number 110M240, 2013. Final Report.

[13] Map Data. https://earth.google.com/web/ (Date of Access: 06.02.2020)

[14] Yalin, M.S. 1971. Theory of Hydraulic Models. Macmillan Publishers Limited, Palgrave. London, 1971.

[15] User Manual. 2011. e+ WATER L. Eijkelkamp Agrisearch Equipment. Giesbeek, Netherlands.

[16] User's Guide. 2002. UVP Monitor Model UVP-DUO with Software Version 3. Met-Flow SA. Lausanne, Switzerland 